\title{
Estimating the freezing and supercooling points of Korean agricultural products from experimental and quality characteristics
}

\author{
Jong Woo Park ${ }^{1 *}$, Jinse Kim${ }^{1}$, Seok Ho Park ${ }^{1}$, Dong Soo Choi ${ }^{1}$, Seung Ryul Choi ${ }^{1}$, \\ Yong Hoon Kim ${ }^{1}$, Soo Jang Lee ${ }^{1}$, Chun Wan Park ${ }^{1}$, Gui Jeung Han ${ }^{2}$ \\ ${ }^{1}$ Division of Postharvest Engineering, National Institute of Agricultural Science, RDA, Wanju 54875, Korea \\ ${ }^{2}$ Division of Agro-Food Utilization, National Institute of Agricultural Science, RDA, Wanju 54875, Korea
}

\section{국내산 농산물의 과냉각 및 동결점 분석}

\author{
박종우 $^{1 *} \cdot$ 김진세 $^{1} \cdot$ 박석호 $^{1} \cdot$ 최동수 $^{1} \cdot$ 최승렬 $^{1} \cdot$ 김용훈 $^{1} \cdot$ 이수장 $^{1} \cdot$ 박천완 $^{1} \cdot$ 한귀정 $^{2}$ \\ ${ }^{1}$ 농촌진흥청 국립농업과학원 수확후관리공학과, \\ ${ }^{2}$ 농촌진흥청 국립농업과학원 가공이용과
}

\begin{abstract}
This study was performed to determine the optimal freezing point for the reliable cold storage of Korean agricultural products, and to provide basic data for determining the storage temperature based on the quality characteristics. Additional supercooling temperature analysis was conducted to explore the possibility of supercooling storage. To determine the effects of quality characteristics on the freezing point, the hardness, acidity, moisture and sugar content were analyzed. The crops were frozen using customized cooling unit and their freezing and supercooling points were determined based on their heat release points. The freezing temperatures of garlic, leek, cucumber, hot pepper, grape, oriental melon, netted melon, peach, cheny tomato, plum, daikon, sweet persimmon, apple, sweet potato, mandarin, pear, and strawberry were $-1.6,-0.5,-0.5,-0.7,-1.6,-1.6,-1.3,-0.8,-0.3,-1.1,-0.3,-1.7,-1.5,-1.5$, $-0.8,-1.5$, and $-0.9^{\circ} \mathrm{C}$, respectively; otherwise, supercooling points were $-7.8,-3.7,-3.3,-4.9,-5.7,-4.6,-2.8,-3.3$, $-5.9,-4.2,-0.8,-4.7,-3.2,-3.7,-4.7,-4.2$, and $-3.4^{\circ} \mathrm{C}$, respectively. These results suggest that the ideal freezing temperature of crops could be estimated through freezing point depression because of their sugar content, and this technique should be used to maintain an optimum storage temperature. However, cold storage is complicated and further study is required because of the effects of long-term cold storage on the crops.
\end{abstract}

Key words : freezing point, supercooling, cold storage, freezing point depression

\section{서 론}

농산물의 저온저장은 저장기한을 연장하는데 있어 최적 의 방법으로, 낮은 저장온도는 세포의 물리적, 생화학적 반응 및 생리대사 속도를 둔화시키고 저장력을 증진시키게 된다(1). 생물체 내에서는 $10^{\circ} \mathrm{C}$ 의 온도 상승에 따라 생리대

*Corresponding author. E-mail : jwpark0824@chosun.kr Phone : 82-63-238-4124, Fax : 82-63-238-4105

Received 12 May 2016; Revised 9 June 2016; Accepted 9 June 2016.

Copyright (c) The Korean Society of Food Preservation. All rights reserved.
사는 2 3배 증가하게 되며, 0 에서 $10^{\circ} \mathrm{C}$ 온도 범위 내에서의 대사속도 차이는 더 크게 나타난다(2). 저장기간을 최대로 연장하기 위한 동결점 저장의 경우 동결점에 근접한 상태로 저장하기 때문에 대상 농산물의 정확한 동결점 파악이 필요 하다. 동결점에 대한 정확한 분석 없이 과도한 저온저장 및 예냉은 농산물의 동해를 유발하여 상품가치 손실 문제를 발생시킨다. 이처럼 농산물 저장에 있어 온도관리가 중요 함에도 불구하고, 국내에서 사용되는 농산물의 저온저장에 대한 대부분의 온도자료는 농산물은 생육환경, 품종 및 기 후에 따라 저장온도가 달라질 수 있음을 고려하지 못 한 채 대부분 일본, 미국과 같은 국외 자료를 바탕으로 하여 저장온도 설정을 하고 있다 $(3,4)$. 또한 많은 농산물에서 일 
반적인 동결온도 범위는 이미 제시되어 있으나 이론적인 동결점 원리를 이용한 분석은 드문 실정으로 정밀한 온도제 어 시스템을 이용한 국내산 농산물의 동결점에 대한 분석 및 고찰이 필요한 실정이다.

동결이론에 따르면 빙결정이 생성되기 이전에 동결점 이하로 내려가는 과냉각(supercooling)점을 지나게 되며 빙 결정이 생성되면서 열방출 현상이 나타나 온도가 급격히 상승하여 동결점에 이르게 된다. 동결점에서 수분이 얼음 으로 상변화가 완료되면 온도는 다시 낮아지게 된다. 따라 서 농산물에 대하여 정밀제어 냉동장치를 이용한 동결온도 처리 시 실시간 온도기록계(data logger)를 이용한 열방출 현상관측 통해 동결점 및 과냉각 점을 분석할 수 있다. 농산물의 저장온도를 결정하기 위하여 각각의 농산물에 대한 동결점 측정은 현실적으로 어려움이 있지만, 농산물 의 동결에 영향을 미치는 요인으로 동결시간은 크기, 표면 열 전달계수, 시료의 초기온도, 시료의 열 물성(수분함량, 비열, 밀도, 열전도도)에 대한 영향을 받게 되며 크기와 표면 열 전달계수에 의한 동결시간 변화가 가장 큰 것으로 보고되고 있다(5). 또한 동결점은 당, 염, 아미노산 및 무기 염류와 같은 영양소들에 의하여 영향을 받으며 그 중 당 함량에 가장 큰 영향을 받는 것으로 보고되고 있다 $(6,7)$.

따라서 본 연구에서는 정밀냉동 및 온도기록 장치를 이 용한 국내산 농산물의 동결점 측정값과 당함량에 따른 동결 점 내림 온도와의 상관관계 분석을 통하여 수확된 농산물의 당함량을 통한 저장온도 설정 가능성에 대한 조사 결과를 소개하고자 한다.

\section{재료 및 방법}

\section{국내산 농산물시료}

본 실험에 사용된 농산물은 2015년도에 국내에서 수확된 신선한 농산물을 이용하였으며, 수확시기 및 산지는 마늘 의 경우 해남과 의성에서 5 6월 중 수확된 마늘, 7월 수확한 김포 대파, 홍천 백오이, 진주 풋고추, 김제 백구포도, 성주 참외 및 곡성 머스크 메론, 9월 수확된 곡성 유명 복숭아, 부여 방울토마토, 이천 장호원황도, 의성 추희 자두, 진안 호박고구마 및 해남 밤고구마, 10 월 수확된 평창 무 및 이서 배, 11 월 수확된 광주 부유단감, 충주 후지사과 및 서귀포 감귤, 12 월 수확된 곡성의 설향 딸기 등 20 개 품목에 대하여 도매상을 통해 특 상품을 구입 후 시료의 특성분석 및 동결 점 분석을 수행하였다. 마늘의 경우 박피 후 절편을 이용하 였으며, 대파는 연백부를 기준으로 분석하였다. 그밖에 농 산물은 세척하지 않은 원물상태로 외관이 양호한 것만을 선별하고, 크기에 대해서는 무작위로 분석을 수행하였다.

\section{시료 농산물의 특성분석}

수확 적기에 수확된 각 농산물의 품질 특성을 분석하기
위하여 $\mathrm{pH}$, 경도, 수분함량 및 당도를 조사하였다. 경도 측정은 각 농산물을 유사한 두께로 절단하여 경도계 (TA-XT2, Stable Micro System Ltd., Godalming, UK)에 5 $\mathrm{mm}$ probe(TA-55; $5 \mathrm{~mm}$ dia., $35 \mathrm{~mm}$ long, $\mathrm{ss}$ )를 장착하고 $1 \mathrm{~mm} / \mathrm{sec}$ 의 속도로 $5 \mathrm{~mm}$ 까지의 최대 압축 강도를 측정하였 으며, 표피가 얇거나 없는 경우는 표면의 경도를 측정하여 최대강도를 N 단위로 나타내었다. 각 농산물의 수분 함량은 상압가열건조법을 이용하여 측정하였으며, 농산물의 당도 및 $\mathrm{pH}$ 를 측정하기 위하여 믹서(HMF-1000, Hanil, Seoul, Korea)를 이용하여 분쇄 및 착즙한 후 디지털 굴절당도계 (RX-5000a, Atago Co., Tokyo, Japan)로 당도를 측정하여 ${ }^{\circ} \mathrm{Brix}$ 단위로 나타내었고, 농산물의 $\mathrm{pH}$ 는 착즙액을 증류수 에 희석 후 $\mathrm{pH}$ 측정기(Orion Star A221, Thermo scientific, Beverly, MA, USA)를 이용하여 측정하였다.

\section{농산물의 동결 및 과냉각 점 분석}

동결점 분석을 위한 냉동고는 정밀한 온도 제어를 위하 여 $1{ }^{\circ} \mathrm{C}$ 단위로 온도조절이 가능한 냉매 가스 및 실리콘 냉각 오일을 이용한 이원냉각방식의 강제 송풍식 냉동기를 자체 제작하여 사용하였다. 이는 냉매에 의해 냉각된 실리 콘 오일을 순환시키고 냉기를 송풍 시키는 방식으로 냉동고 내부의 온도 센서와 외부의 컴퓨터를 통한 정밀 온도제어가 가능하다. 씨방이 없는 농산물의 경우 적도면 중심부에, 씨방이 존재하는 농산물의 경우 적도면의 과육 두께를 측정 한 후 그 중심부까지 온도센서(ALMEMO 2290-8, Ahlborn, Holzkirchen, Germany)를 삽입하고 온도를 $4^{\circ} \mathrm{C}$ 에서 $-15^{\circ} \mathrm{C}$ 까 지 $1^{\circ} \mathrm{C}$ 씩 감소시켰다. 이때 각 온도 구간은 농산물의 부피에 따라 전체가 동일한 온도를 이룰 때까지(30 60분) 유지 시 키며 30초 간격으로 10 15시간 까지 측정 및 수집하였다. 농산물의 동결점 및 상변화는 Park 등(8)에 따라 열방출 현상 분석을 통하여 판단하였다.

\section{당함량에 따른 농산물의 동결점 내림분석}

굴절당도계에 의해 측정되는 당함량은 자당, 포도당, 과 당, 및 소르비톨과 같은 전체 당에 대한수치로서 분석 된 농산물에 포함된 당중 평균 분자량을 가지는 자당의 몰랄

$$
\begin{aligned}
& \left.\Delta \quad \begin{array}{c}
R T_{0} M_{1} \\
1000 \Delta H f
\end{array}\right) m \\
& \Delta T_{f}=K_{f} m
\end{aligned}
$$

\footnotetext{
$\Delta T_{f}$ : the freezing point depression

$R$ : gas constant (joule/mol $\mathrm{K}$ )

$T_{0}$ : freezing temperature of the solvent

$M_{1}$ : molar mass of the substance dissolved

$m$ : molar mass of the solvent

$\Delta H_{f}$ : latent heat of freezing

$K_{f}$ : kinetic constant of freezing (water $=1.858^{\circ} \mathrm{C} / \mathrm{m}$ )
} 
농도를 이용하여 Blagden's Law(9)의 물에 대한 동결점 내 림 관계식에 따라 동결점을 계산하였다.

\section{결과 및 고찰}

농산물의 특성분석

동결점 분석을 위한 공시 재료의 평준화를 위한 국내산 농산물의 품질 분석 결과를 Table 1에 나타내었다. 대표적 인 조미 채소인 마늘은 저장에 적합하도록 예건 된 상태로 66 69\%의 함수율을 나타내었고 경도 및 당도는 북방계열 의 마늘에서 소폭 높은 경향을 나타냈었다. 마늘을 제외한 신선 대파, 오이, 고추, 무 및 토마토에서는 $90 \%$ 이상의 높은 함수율을 나타낸 반면 대체적으로 $5{ }^{\circ} \mathrm{Brix}$ 이하의 낮은 당도를 나타내었으며, 포도, 참외, 메론, 복숭아, 자두, 감, 사과, 고구마, 배 및 딸기 등에서는 대부분 $90 \%$ 이하의 함수율을 나타낸 반면 당도는 7 15 ${ }^{\circ}$ Brix 가량으로 비교적 높게 나타났다. 농산물의 품질을 평가하기 위한 주요 인자 로서는 크기, 모양, 색 및 맛 등이 있으며, 크기 및 모양은 심리적 만족감을 통해 소비자의 기호를 충족시키기는 반면 색과 맛 등은 기호적 품질 및 생산 유통단계에서의 품질을
판단하는 지표로 이용된다(10). 생산 유통단계에서의 색은 농산물의 성숙도 및 신선도의 판별기준이 될 수 있으며, 감미(甘味) 및 산미(酸味)와 수분 함량 및 질감에 의해 결정 되는 식감을 포함하는 맛 또한 품질 평가의 지표로 사용된 다(11). 이러한 품질평가 지표에 따른 저장온도 조건 설정이 가능하다면 국내산 농산물의 유통품질의 향상에도 기여할 수 있을 것으로 판단된다.

\section{농산물의 동결 및 과냉각 점 분석}

동결온도 분석을 위한 이원냉각 냉동기를 Fig. 1 에 나타 내었다. 냉동기의 최저 냉동온도는 $-40^{\circ} \mathrm{C}$ 이었으며, 온도 설 정구간에서의 냉각 속도는 $-0.25^{\circ} \mathrm{C} / \mathrm{min}$ 를 나타내었고, 온도 유지구간의 편차는 $0.5^{\circ} \mathrm{C}$ 이내로 매우 정밀한 온도제어가 가능하였다. 제작된 냉동기를 이용한 동결온도 처리 시 증 류수의 경우 과냉각 한계온도는 $-11.9 \pm 0.9^{\circ} \mathrm{C}$ 였으며, 동결점 은 $0 \pm 0.5^{\circ} \mathrm{C}$ 였다. 마늘, 대파, 오이 및 포도의 냉각 및 열방출 그래프를 Fig. 2A에 나타내었다. 열방출 현상에 기초한 마 늘(의성/ 해남), 대파, 오이, 포도의 과냉각 한계온도는 각각 $-7.7 /-7.8,-3.6,-3.2$ 및 $-5.7^{\circ} \mathrm{C}$ 였으며, 동결점은 $-1.6 /-1.3$, $-0.4,-0.45$ 및 $-1.6^{\circ} \mathrm{C}$ 로 확인되었다. 본 연구에서 확인된 마늘의 동결점은 $-1.3 \sim-1.6^{\circ} \mathrm{C}$ 로 Park 등(12)의 국산 마늘의

Table 1. Quality characteristics of Korean agricultural products

\begin{tabular}{|c|c|c|c|c|}
\hline Agricultural products & Moisture (\%) & Hardeness (skin/flesh) $(\mathrm{N})$ & $\begin{array}{l}\text { Sugar } \\
\left({ }^{\circ} \text { Brix }\right)\end{array}$ & $\mathrm{pH}$ \\
\hline Garlic (southern-type) & $66.5 \pm 0.6^{1)}$ & $34.1 \pm 3.8$ & $32.0 \pm 1.4$ & $5.97 \pm 0.3$ \\
\hline Garlic (northern-type) & $68.7 \pm 0.4$ & $41.8 \pm 4.3$ & $35.0 \pm 1.9$ & $6.04 \pm 0.3$ \\
\hline Leek & $90.4 \pm 0.2$ & $31.0 \pm 6.4$ & $3.1 \pm 0.6$ & $5.92 \pm 0.4$ \\
\hline Cucumber & $95.5 \pm 0.3$ & $32.3 \pm 2.4$ & $4.5 \pm 0.4$ & $6.21 \pm 0.3$ \\
\hline Hot pepper & $92.3 \pm 0.4$ & $21.6 \pm 2.2$ & $5.1 \pm 0.4$ & $5.32 \pm 0.5$ \\
\hline Grape & $86.7 \pm 0.9$ & $5.3 \pm 1.6$ & $15.3 \pm 0.8$ & $3.40 \pm 0.3$ \\
\hline Oriental melon & $90.6 \pm 0.7$ & $40.5 \pm 5.1 / 18.4 \pm 2.6$ & $14.5 \pm 1.1$ & $5.47 \pm 0.5$ \\
\hline Netted melon & $86.7 \pm 0.7$ & $63.9 \pm 4.8 / 27.4 \pm 2.1$ & $12.5 \pm 1.1$ & $6.13 \pm 0.6$ \\
\hline Peach (white) & $90.6 \pm 0.3$ & $24.1 \pm 2.4 / 13.6 \pm 1.0$ & $13.2 \pm 0.8$ & $4.21 \pm 0.7$ \\
\hline Peach (yellow) & $85.1 \pm 0.4$ & $17.1 \pm 1.6 / 7.1 \pm 1.2$ & $14.1 \pm 0.7$ & $4.63 \pm 0.4$ \\
\hline Cherry tomato & $94.1 \pm 0.2$ & $15.6 \pm 2.4$ & $4.9 \pm 0.3$ & $4.41 \pm 0.5$ \\
\hline Plum & $87.6 \pm 0.7$ & $20.8 \pm 2.7$ & $13.9 \pm 0.4$ & $3.48 \pm 0.6$ \\
\hline Daikon & $95.3 \pm 0.3$ & $28.9 \pm 3.7$ & $4.3 \pm 0.6$ & $6.08 \pm 0.2$ \\
\hline Sweet persimon & $84.2 \pm 0.3$ & $38.8 \pm 4.1$ & $13.8 \pm 0.8$ & $6.00 \pm 0.4$ \\
\hline Apple & $83.9 \pm 0.4$ & $32.7 \pm 4.2 / 13.9 \pm 2.1$ & $15.8 \pm 0.6$ & $3.65 \pm 0.6$ \\
\hline Sweet potato (chestnuts) & $69.5 \pm 0.4$ & $59.7 \pm 4.5$ & $6.9 \pm 1.1$ & $5.90 \pm 0.4$ \\
\hline Sweet potato (pumpkin) & $71.4 \pm 0.4$ & $57.6 \pm 6.2$ & $7.2 \pm 1.2$ & $6.40 \pm 0.3$ \\
\hline Mandarin (citrus) & $90.1 \pm 0.3$ & $7.3 \pm 3.6$ & $9.7 \pm 0.8$ & $3.72 \pm 0.4$ \\
\hline Pear & $82.7 \pm 0.5$ & $22.1 \pm 2.5 / 15.1 \pm 2.1$ & $16.0 \pm 0.8$ & $5.10 \pm 0.4$ \\
\hline Strawberry & $89.7 \pm 0.3$ & $2.2 \pm 0.3$ & $9.5 \pm 0.5$ & $3.80 \pm 0.3$ \\
\hline
\end{tabular}

${ }^{1)}$ The values represent mean \pm SD for six experiments. 
A
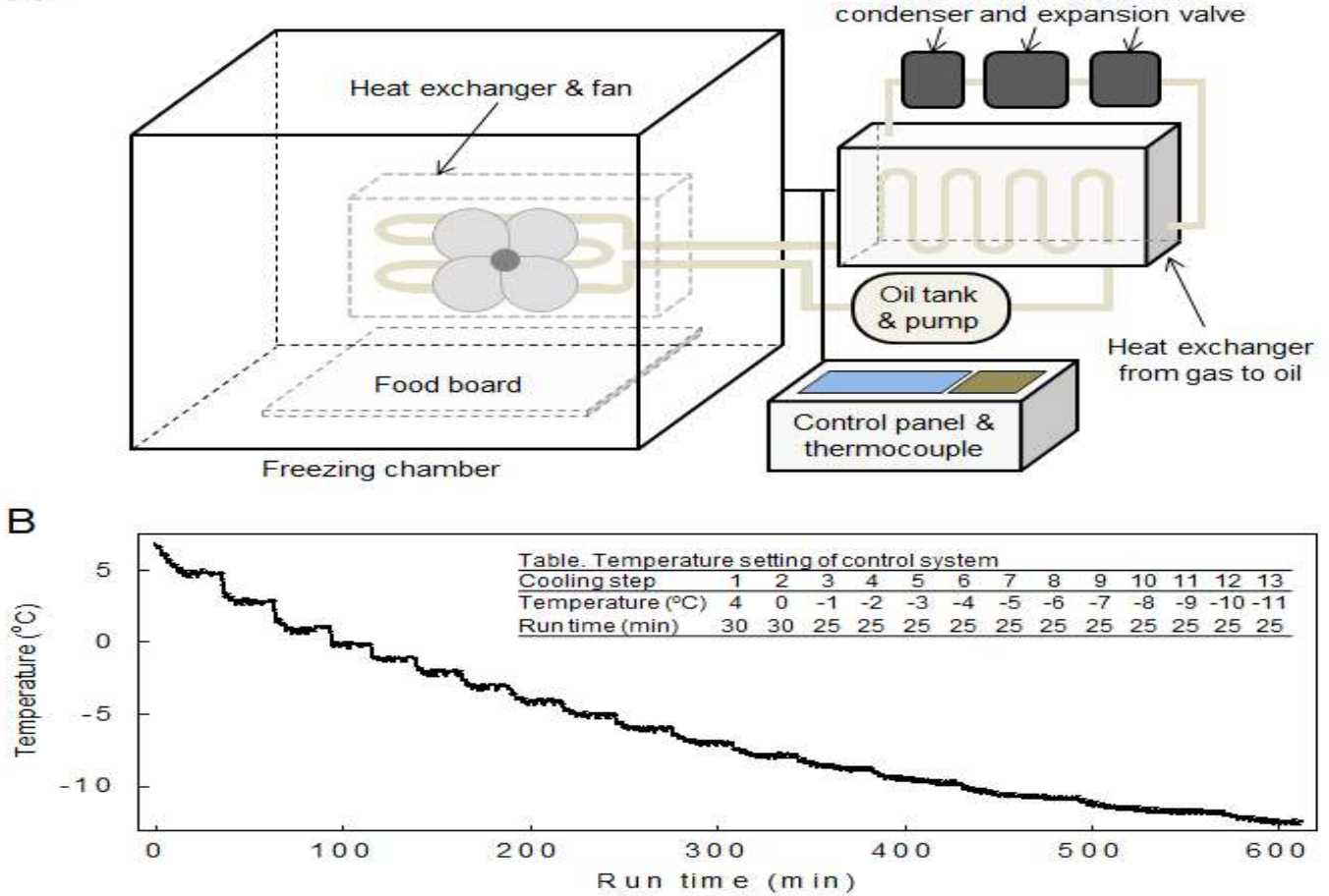

Fig. 1. Schematic diagram of the customized freezing system (A) and the temperature properties of the freezing chamber (B).
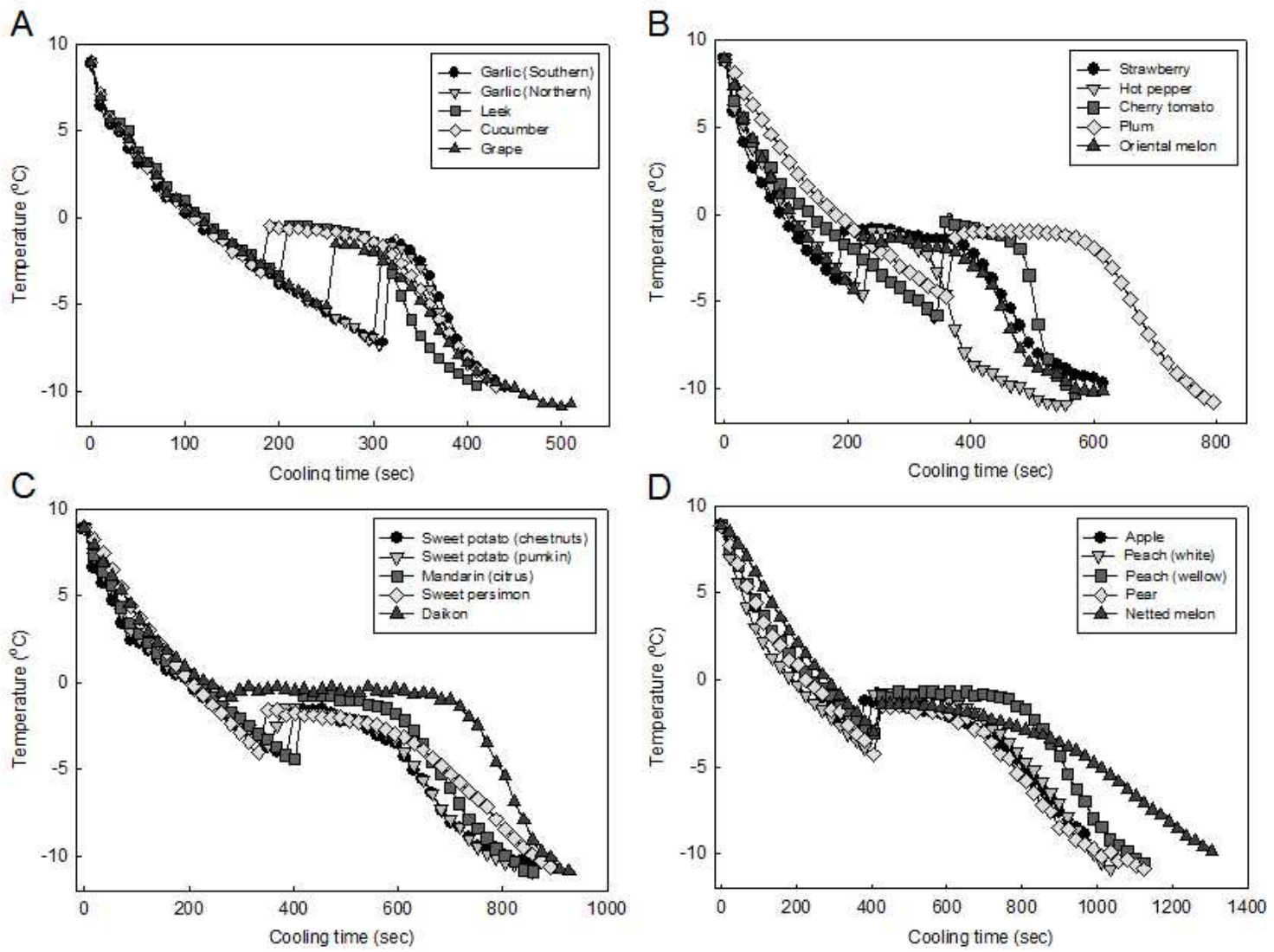

Fig. 2. Representative freezing curves of garlic, leek, cucumber, and grape (A); strawberry, hot pepper, cherry tomato, plum, and oriental melon (B); sweet potato, mandarin, sweet persimmon, and daikon (C); and apple, peach, pear, and netted melon (D). 
동결점 $-3.0 \sim-5.5^{\circ} \mathrm{C}$ 및 James(13)가 밝힌 $-2.7^{\circ} \mathrm{C}$ 에 비하여 높게 나타냈으며, 이는 선행연구에서는 구근형태로 동결점 을 분석하였으나 본 연구에서는 껍질이 제거된 절편을 이용 한 조건에 대한 차이로 판단된다. 딸기, 풋 고추, 방울토마 토, 자두 및 참외의 냉각 및 열방출 현상은 Fig. $2 \mathrm{~B}$ 에 나타낸 바와 같이 농산물 각각의 과냉각 한계온도는 $-4.2,-4.9,-5.9$, -4.7 및 $-4.6^{\circ} \mathrm{C}$ 에 동결점은 $-0.8,-0.6,-0.3,-1.0$ 및 $-1.4^{\circ} \mathrm{C}$ 였다. 딸기의 경우 기존에 밝혀진 동결점 $-1.3^{\circ} \mathrm{C}(7)$ 에 비하 높게 나타났으며, 그밖에 고구마(호박/밤), 감귤, 단감, 김장 무에 대한 냉각 및 열방출 현상을 분석한 결과 (Fig. 2C) 각 농산물의 과냉각 한계온도는 -1.4/-3.7, -4.7, -4.7 및 -0. $8^{\circ} \mathrm{C}$, 동결점은 $-1.6 /-1.4,-0.8,-1.6$ 및 $-0.3^{\circ} \mathrm{C}$ 로 확인 되었다. 단감의 경우 기존에 밝혀진 동결점 $-2.5^{\circ} \mathrm{C}(14)$ 보다 높은 온 도에서 동결이 일어나는 것으로 확인되었다. Fig. $2 \mathrm{D}$ 에 나 타낸 사과, 복숭아(백도황도), 배 및 메론의 냉각 및 열방출 그래프에서 각 농산물의 과냉각 한계온도는 $-3.1,-3.2 /-3.5$, -4.2 및 $-2.8^{\circ} \mathrm{C}$ 이였으며, 동결점은 $-1.4,-0.8 /-0.7,-1.5$ 및 $-1.2^{\circ} \mathrm{C}$ 로 확인 되었다. 이는 Jeong 등(7)의 연구에서 사과의 동결점 $-1.4^{\circ} \mathrm{C}$ 와 배 및 메론의 동결점으로 밝힌 $-1.2^{\circ} \mathrm{C}$ 와
기존 복숭아의 동결온도 $-0.7 \sim-1.0^{\circ} \mathrm{C}(8)$ 와 유사한 결과이다. 분석이 이루어진 대부분의 과일류 농산물에서도 동결점에 차이를 보이는 품목이 많을 뿐만 아니라 대파, 오이, 고추, 고구마 및 무와 같은 채소류에 대한 분석은 찾기 힘들며, 대부분 국외자료(15)를 바탕으로 저장온도에 대하여 논하 고 있다. 따라서 농산물의 저온저장 시 동해방지를 통한 품질향상을 도모하기 위하여 더욱 다양한 국내산 농산물에 대한 저장온도 분석이 필요하며 정확한 저장 온도에 대한 홍보가 필요할 것으로 판단된다. 또한 각 농산물의 과냉각 한계점은 동결점에 비하여 $0.5 \sim 6.4^{\circ} \mathrm{C}$ 가량 낮게 나타나 과 냉각 저장의 경우 저장기간을 더욱 연장 시킬 수 있을 것으 로 판단되나, 과냉각 저장의 장기간 유지가 어려웠다. 이는 빙핵 형성 물질 등 외부 자극에 의한 과냉각 유지 균형이 깨어진 것으로 판단되며, 또한 현실적으로는 온도편차가 발생하지 않은 저장고 제작의 한계가 있어 추가적인 연구가 필요할 것으로 판단된다.

\section{당함량에 따른 동결점 분석}

농산물의 동결점에 가장 큰 영향을 미치는 요인으로 알

Table 2. Freezing point depression depends on the sugar contents and nucleation points of the agricultural products

\begin{tabular}{|c|c|c|c|c|c|}
\hline \multirow{2}{*}{ Agricultural products } & \multirow{2}{*}{ Sugar $(g / L)$} & \multirow{2}{*}{$\begin{array}{c}\text { Molality } \\
(\mathrm{mol} / \mathrm{kg})\end{array}$} & \multicolumn{3}{|c|}{ Temperature $\left({ }^{\circ} \mathrm{C}\right)$} \\
\hline & & & Depression $^{2)}$ & Freezing & Super-cooling \\
\hline Garlic (southern-type) & 320 & 1.778 & 3.307 & $-1.4 \pm 0.2^{3)}$ & $-7.8 \pm 0.6$ \\
\hline Garlic (northern-type) & 350 & 1.944 & 3.617 & $-1.6 \pm 0.2$ & $-7.7 \pm 0.8$ \\
\hline Leek & 31 & 0.172 & 0.320 & $-0.5 \pm 0.1$ & $-3.7 \pm 0.1$ \\
\hline Cucumber & 45 & 0.211 & 0.465 & $-0.5 \pm 0.1$ & $-3.3 \pm 0.2$ \\
\hline Hot pepper & 51 & 0.283 & 0.527 & $-0.7 \pm 0.4$ & $-4.9 \pm 0.6$ \\
\hline Grape & 153 & 1.017 & 1.891 & $-1.6 \pm 0.1$ & $-5.7 \pm 0.8$ \\
\hline Oriental melon & 145 & 0.806 & 1.498 & $-1.6 \pm 0.3$ & $-4.6 \pm 1.6$ \\
\hline Netted melon & 125 & 0.694 & 1.292 & $-1.3 \pm 0.1$ & $-2.8 \pm 0.2$ \\
\hline Peach (white) & 132 & 0.733 & 1.364 & $-0.8 \pm 0.1$ & $-3.3 \pm 0.8$ \\
\hline Peach (yellow) & 141 & 0.783 & 1.457 & $-0.8 \pm 0.1$ & $-3.3 \pm 0.1$ \\
\hline Cherry tomato & 49 & 0.272 & 0.506 & $-0.3 \pm 0.1$ & $-5.9 \pm 0.2$ \\
\hline Plum & 139 & 0.772 & 1.436 & $-1.1 \pm 0.2$ & $-4.2 \pm 1.9$ \\
\hline Daikon & 43.2 & 0.239 & 0.443 & $-0.3 \pm 0.1$ & $-0.8 \pm 0.3$ \\
\hline Sweet persimon & 137.5 & 0.760 & 1.413 & $-1.7 \pm 0.3$ & $-4.7 \pm 0.2$ \\
\hline Apple & 158.2 & 0.877 & 1.629 & $-1.5 \pm 0.2$ & $-3.2 \pm 0.1$ \\
\hline Sweet potato (chestnuts) & 69 & 0.381 & 0.709 & $-1.5 \pm 0.4$ & $-3.7 \pm 0.5$ \\
\hline Sweet potato (pumpkin) & 72.2 & 0.401 & 0.745 & $-1.6 \pm 0.3$ & $-4.4 \pm 0.8$ \\
\hline Mandarin (citrus) & 97 & 0.538 & 1.000 & $-0.8 \pm 0.2$ & $-4.7 \pm 0.2$ \\
\hline Pear & 160 & 0.888 & 1.650 & $-1.5 \pm 0.2$ & $-4.2 \pm 0.3$ \\
\hline Strawberry & 95 & 0.527 & 0.980 & $-0.9 \pm 0.2$ & $-3.4 \pm 0.1$ \\
\hline
\end{tabular}

\footnotetext{
${ }^{1)}$ Molality was obtained from the molecular formula of fructose (FW: 180.16).

${ }^{2)}$ The molal freezing point depression constant value for water is $1.858^{\circ} \mathrm{C} / \mathrm{m}$.

${ }^{3)}$ The values represent mean \pm SD for three experiments.
} 
려진(16) 당함량에 따른 농산물의 동결 예측 온도를 Table 2 에 나타내었다. 마늘의 경우 당함량에 따른 동결점은 -3 . $3^{\circ} \mathrm{C}$ 로 분석된 동결점 $-1.4^{\circ} \mathrm{C}$ 와 큰 차이를 나타내었지만, 대 파, 오이, 고추, 포도, 멜론, 토마토 등 대부분의 농산물에서 실측된 동결점과 유사하게 나타났으며, 당도가 높은 농산 물 일수록 동결점이 낮은 경향을 나타내었다. 이는 작황 및 산지에 따른 농산물의 품질 차이를 고려한 저장온도 결정에 이용될 수 있을 것으로 판단된다. 최근 비파괴 선별 기술이 발전함에 따라 당도에 따른 선별 및 유통이 일반화 되는 가운데 저장에서도 선별된 당도 정보를 이용한 최적의 저장온도 설정을 통해 고품질 농산물의 저장이 가능할 것으 로 판단된다.

\section{요 약}

본 연구는 국내산 농산물의 안정적인 저온저장온도 결정 을 위하여 동결점을 분석하고 품질에 따른 저장온도 설정에 대한 기초자료를 제공하고 과냉각 한계점 측정을 통하여 과냉각 저장 가능성을 모색하고자 수행되었다. 동결점 및 과냉각 한계온도를 분석하기 위하여 국내산 마늘, 오이, 대파, 고추, 참외, 메론, 복숭아, 자두 등의 국내산 농산물을 자체 제작한 송풍식 냉동기를 이용하여 완만 냉각시키면서 농산물 내부에 삽입된 온도센서를 이용하여 열방출을 측정 하였다. 또한 일반 품질특성 인자들이 각 농산물 동결점에 미치는 영향을 분석하기 위하여 당도, 산도, 함수율 및 경도 를 측정하였다. 열방출 최고점을 기준으로 판단한 농산물 의(동결점/과냉각 한계점)은 마늘 $\left(-1.6 /-7.8^{\circ} \mathrm{C}\right)$, 대파(-0.5/ $\left.-3.7^{\circ} \mathrm{C}\right)$, 오이 $\left(-0.5 / 3.3^{\circ} \mathrm{C}\right)$, 풋고추 $\left(-0.7 /-4.9^{\circ} \mathrm{C}\right)$, 포도(-1.6/-5. $\left.7^{\circ} \mathrm{C}\right)$, 참외(-1.6/-4.6 $\left.{ }^{\circ} \mathrm{C}\right)$, 메론(-1.3/-2.8 $\left.{ }^{\circ} \mathrm{C}\right)$, 복숭아 $(-0.8 /-3$. $\left.3^{\circ} \mathrm{C}\right)$, 방울토마토 $\left(-0.3 /-5.9^{\circ} \mathrm{C}\right)$, 자두 $\left(-1.1 /-4.2^{\circ} \mathrm{C}\right)$, 무 $(-0.3 /-0$. $\left.8^{\circ} \mathrm{C}\right)$, 단감 $\left(-1.7 /-4.7^{\circ} \mathrm{C}\right)$, 사과 $\left(-1.5 /-3.2^{\circ} \mathrm{C}\right)$, 고구마 $(-1.5 /-3$. $\left.7^{\circ} \mathrm{C}\right)$, 감귤 $\left(-0.8 /-4.7^{\circ} \mathrm{C}\right)$, 배 $\left(-1.5 /-4.2^{\circ} \mathrm{C}\right)$, 딸기 $\left(-0.9 /-3.4^{\circ} \mathrm{C}\right)$ 이 었다. 이러한 동결점은 각 농산물의 이화학적 특성분석에 비추어 볼 때 당 성분에 따른 동결점 내림 경향과 일치하여 당도분석을 통한 저장온도 설정 가능성을 제시하였다.

\section{감사의 글}

본 연구는 2016년도 농촌진흥청 공동연구사업(과제번 호: PJ01083601) 및 국립농업과학원 박사후 연수과정 지원 사업에 의해 이루어진 것이며, 이에 감사드립니다.

\section{References}

1. Rutherford PP, Whittle R (1982) The carbohydrate composition of onions during long term cold storage. J Hort sci, 57, 349-356

2. Kim YB, Yasutaka K, Akitsugu I, Reinosuke N (1996) Effect of storage temperature on keeping quality of tomato and strawberry fruits. J Kor Soc Hort Sci, 37, 526-532

3. Auleda JM, Raventos M, Sanchez J, Hernandez E (2011) Estimation of the freezing point of concentrated fruit juices for application in freeze concentration. J Food Eng, $105,289-294$

4. Hanover LM, White JS (1993) Manufacturing, composition, and application of fructose. AM J Clin Nutr, 58, 724-732

5. Jeong JW, Kim JH, Park NH, Lee SH, Kim YD (1998) Freezing time prediction of foods by multiple regression analysis. Korean J Food Sci Technol, 30, 341-347

6. Miles CA, Mayer Z, Morley MJ, Houska M (1997) Estimating the initial freezing point of foods from composition data. Int J Food Sci Technol, 32, 389-400

7. Jeong JW, Jeong SW, Park KJ (2003) Changes in internal pressure of frozen fruits by freezing methods. Korean J Food Preserv, 10, 459-465

8. Park YM, Hong YP (2009) Methodological approach to evaluate freezing points of peach and apple fruits through exotherm study. Kor J Hort Sci Technol, 27, 601-606

9. Blagde C (1775) Experiments and Observations in an Heated Room. Philosophical Transactions, 65, 111-123

10. Hong YP, Choi SY, Cho MA, Choi ST, Kim SJ (2010) Correlation between soluble solid content and physicochemical properties of 'Bing' cherry at different stages of ripening after harvest. Korean J Food Preserv, 17, 370-375

11. Kim JY, Kwon KH, Gu KH, Kim BS (2011) Selection of quality indicator to determine the freshness of muskmelon (Cucumis melo L.) during distribution. Korean J Food Preserv, 18, 824-825

12. Park MH, Kim JP, Shin DB (1988) Studies on cold resistance of garlic bulbs at subzero temperature. Korean J Food Sci Technol, 20, 200-204

13. James C, Seignemartin V, James SJ (2009) The freezing and supercooling of garlic (Allium sativum $\mathrm{L}$.). Int $\mathbf{J}$ Refrig, 32, 253-260

14. Kim JY, Kim IH, Jeong DY, Chung DS, Lee YJ (2014) Analysis of freezing temperature through exotherm according to maturity and part of fruit of sweet persimmon and apple. Kor J Hort Sci Technol, 32, 44-45

15. Hardenburg RE, Watada AE, Wang CY (1986) The commercial storage of fruits, vegetables, and florist and 
nursery stocks. USDA Handbook no.66, Washington DC, USA, p 30
16. Hanover LM, White JS (1993) Manufacturing, composition, and application of fructose. AM J Clin Nutr, 58, 724-732 